\title{
Fire trin mod udbytterige studenteroplæg - hvordan præsentationer i undervisningen høj- ner fagligheden og bliver en positiv oplevelse
}

\author{
Linda Greve, ph.d.-stipendiat, uddannelsesudvikler, Center for Undervisning og \\ Læring, Aarhus BSS, Aarhus Universitet
}

Faglig artikel (bedømt af redaktionen)

Studenteroplæg er en både meget anvendt og meget udskældt disciplin. I denne artikel foretages fire nedslag for at hjæe/pe undervisere med mere tydeligt at rammesætte studenteroplæg som læringsaktivitet. De fire nedslag er: 1) Længe for oplægget, hvor aktiviteten indlejres i faget; 2) lige for oplægget hvor underviseren låner lidt af sin troværdighed til den studerende, der skal holde oplæg; 3) under oplægget, hvor underviseren har fokus på aktiv lytning og 4) efter oplægget, hvor feedback på oplagget hjælper de studerende med at få et fagligt sprog. Artiklens fokus er at klæde undervisere på til at få en hensigtsmæessig praksis i forhold til studenteroplæg.

\section{Introduktion: Studenteroplæg i undervisningen}

Studenteroplæg er gavnlige på flere parametre. De studerende lærer mere ved selv at skulle formidle fagligt stof, de får erfaring med at præsentere foran et publikum, og de får mulighed for feedback på deres forståelsesniveau (MacAlpine, 1999). Alligevel ender studenteroplæg alt for ofte med, at de studerende står med ryggen til publikum og læser højt af slides, og at feedbacken bliver usammenhængende og ukonstruktiv. I denne artikel beskrives, hvordan undervisere kan arbejde med at højne niveauet af studenteroplæg i undervisningen gennem fire trin: længe før oplægget, lige før oplægget, under oplægget og efter oplægget. Formålet med at gribe studenteroplæg an på denne måde er at højne læringen hos både den studerende, der holder oplægget, og hos dem, der lytter og giver feedback.

Artiklens faglige ståsted er i retorikken. De metoder, der bliver præsenteret nedenfor, er således situeret i en metodisk tilgang til forberedelse (se fx Greve, 2011; McCroskey, 2001). Uden at gennemgå retorikkens fem forberedelsesfaser slavisk ${ }^{1}$ vil der dog i det følgende være referencer til, hvordan studerende hjælpes til både at lave bedre oplæg og at få gode oplevelser med at holde oplæg, som i høj grad er inspireret af de fem faser. Fokus i artiklen er ikke at beskrive, hvordan man laver gode oplæg, men hvordan man som underviser skaber de fornødne rammer for, at aktiviteten får et udbytte, der svarer til indsatsen både i form af tid i undervisningen og forberedelsestid hos den studerende samt i læringsudbytte.

Ud over funderingen i klassisk retorik er det også centralt at understrege artiklens fundering i en mundtlig tradition (Ong, 2013). Påstanden er, at idealet for et godt studenteroplæg ikke er, hvor tæt det er på skriftlighed, men hvor levende, engagerende og målgrupperettet det er. Det er således med fuldt overlæg, at der tales om oplæg og ikke om præsentationer. Ordet 'præsentationer' konnoterer nemt PowerPoint-præsentationer, og

\footnotetext{
${ }^{1}$ De fem forberedelsesfaser er (oversat til dansk): 1) idéudvikling, 2) disponering, 3) sprog og stil, 4) husketeknik og 5) fremførelse. Logikken i de fem faser er, at man starter med at udforske kommunikationssituationen og på den baggrund opbygger sit oplæg $\mathrm{i}$ indhold, stil, visualisering for sig selv og publikum og endelig selve oplægget.
} 
selvom der ikke er det mindste galt med at anvende teknologi til at visualisere sine pointer, bliver PowerPoint nemt til et manuskript i punktform, man deler med sit publikum. Det ideal, der søges fremelsket i denne artikel, er et relaterende og kommunikerende ideal snarere end et indstuderet og skriftligt ideal. Det handler om at give de studerende rum til frit at udfolde deres forståelse af et fagligt emne og uden den bedømmelse, der ligger til grund for eksamenspræstationer. Det er således vigtigt, at underviseren rammesætter studenteroplæg som en læringsaktivitet og ikke som en bedømmelsesaktivitet: Formålet med studenteroplæg er at styrke evnen til mundtlig argumentation og præsentation frem mod den afsluttende eksamen.

Artiklens klangbund er, ud over den teoretiske, forfatterens mangeårige erfaring med at undervise i præsentationsteknik både for studerende og undervisere samt anvendelse af studenteroplæg i egen undervisning.

Som undervisere har vi en meget stor indflydelse på, hvor vellykket et studenteroplæg bliver. Forståelsen af indholdet og evnen til at strukturere det kan vi i sagens natur ikke altid hjælpe med, men at skabe rammerne for en fagligt funderet kommunikation er underviserens ansvar. I det følgende vises, hvordan dette kan gøres ved brug af eksempler og teori samt forslag til øvelser.

\section{Længe før oplægget}

I planlægningen af undervisningen skal det indgå, om de studerende skal lave oplæg. Studenteroplæg passer godt băde til gennemgang af fagligt stof, til præsentation af gruppearbejde og til præsentation af produkter og af processer. De studerende lærer meget af at forberede et oplæg, og de lærer meget af at høre hinandens, hvis rammerne er klare og formålet tydeligt. Bhatti og Grøn (2014) påviser i deres undersøgelse af studerendes præferencer for undervisningsformer, at studerende foretrækker forelæsning frem for $\mathrm{fx}$ studenteroplæg. En del af forklaringen på dette kan meget vel findes i, at rammerne og formålet er uklart, samt at legitimiteten af en medstuderendes undervisning vurderes lavere. Dette uddybes nedenfor. Hvis studenteroplæg er en del af undervisningen, så er det en fordel at lade dem starte tideligt i forløbet, så det bliver en del af kulturen. Det kan overvejes at lade alle studerende holde først et kort oplæg af redegørende karakter og senere på semesteret et længere og mere selvstændigt. På den måde startes der med noget relativt harmløst og arbejdes der hen imod noget mere selvstændigt og taksonomisk mere komplekst samtidigt med, at der opbygges en god kultur omkring det at holde og lytte til studenteroplæg.

Det er således vigtigt at implementere studenteroplæg som en del af enten læringsmål eller aktivitetskrav for at legitimere aktiviteten og fjerne al tvivl hos de studerende om, hvorvidt det er nødvendigt. Læringsmål kan både være rettet mod, at alle skal holde et eller flere faglige oplæg i løbet af kurset, og mod at alle studerende skal træne evnen til at give feedback på og diskutere fagligt relevant stof. På denne måde rammer læringsmålet både den, der holder oplægget, og de, der er aktivt lyttende.

Næste led er at lave klare rammer for oplægget. Hvor lang tid må det vare, hvilke krav er der til form og vigtigst af alt: hvad er formålet med, at de studerende skal holde oplæg? Disse tre spørgsmål er der ikke ét oplagt og rigtigt svar på. Hvis formålet er at få de studerende til at forstå og formidle fagligt stof, er det en fordel også at give dem god tid til det. Hvis de derimod skal pitche en løsning eller en idé, de har fundet frem til, er fem minutter måske nok, og det centrale er diskussionen og feedbacken bagefter.

Nogle studerende vil se det som en kvalitetsforringelse at skulle undervises af hinanden frem for af underviseren (Bhatti \& Grøn, 2014). Dette sker typisk fordi de studerende er statussensitive over for hinanden - de er formelt på samme niveau - og både for at beskytte sig selv mod at skulle stå foran kammeraterne og for at hævde status over mindre 
dygtige studerende, kan denne form for modstand opstå. Det er i den forbindelse afgørende at hjælpe de studerende til at forstå, hvilket formål aktiviteten tjener.

Ud over situeringen i læringsmål er det også vigtigt at udstikke klare retningslinjer for tid og indhold. Jo mere præcis formen er, desto mere ro har de studerende til at fokusere på indholdet. Hvis det er en kortere præsentation, kan Pecha Kucha overvejes som ramme (Klentzin, Paladino, J ohnston, \& Devine, 2010). De studerende har 20 billeder i hver 20 sekunder til at præsentere deres stof. ${ }^{2}$ Denne form kan med fordel bruges til præsentationer af løsninger og processer, men formen kan også anvendes til forskningsformidling. Formen kommer fra Japan. Pecha Kucha betyder 'snik snak'. Egentlig har metoden sit udspring i designindustrien, men den kan problemfrit også anvendes til forskningsformidling og pitching. Klentzin et al. fremhæver denne metode til pensumgennemgang som særligt velegnet og viser, at studerende kan lære lige så meget af den korte Pecha Kucha som af en traditionel PowerPoint-forelæsning.

Det meget faste format og kravet om illustrationer gør, at de studerende skal tænke lidt anderledes om deres emne, hvilket kan være en passende udfordring både for dem og for tilhørerne. Ulempen ved dette format er, at deltagerne ikke kan improvisere ret meget fordi 20 sekunder er meget kort tid.

Et element, det er vigtigt at tage med sig fra Pecha Kucha, er visualiseringen. Lad de studerende tænke visuelt og ikke kun tekstuelt om deres oplæg. Dermed undgår du, at oplægsholderen står og læser højt af sine slides eller sin skærm frem for at lade ordene og ideerne stå frem.

Et andet element, det er værd at tage med fra Pecha Kucha, er tidsopdelingen. Det er en fordel for den studerende, at der er taget stilling til, hvilke elementer der skal være i oplægget, og hvordan de tidsmæssigt skal disponeres. Underviseren kan med fordel lave en tidsplan, som de studerende selv skal fylde indhold i. Det tager igen fokus væk fra formen og retter det mod indholdet, og så hjælper det den studerende med at disponere stoffet, uden at du behøver at undervise i disponering af stof.

En plan kunne se således ud:

\begin{tabular}{l|l|l} 
Tid (minutter) & Tema & Illustration \\
\hline 3 min. & $\begin{array}{l}\text { Indledning i emnet } \\
\text { Emnets relevans } \\
\text { Oplæggets struktur }\end{array}$ & \\
\hline 13 min. & $\begin{array}{l}\text { Emnets baggrund } \\
\text { Redegørelse for synspunkter } \\
\text { Diskussion af synspunkter }\end{array}$ & \\
\hline 2 min. & $\begin{array}{l}\text { Perspektivering af emnet til resten af } \\
\text { faget }\end{array}$ & \\
& Oplæg til diskussion & \\
\hline I alt 15 minutter & &
\end{tabular}

Figur 1: Skema der hjælper de studerende til at disponere deres indhold og tid samt indikerer et krav om at anvende illustrationer

\footnotetext{
${ }^{2}$ PowerPoint og lignende programmer kan kodes til selv at skifte hvert 20. sekund. Det er relativt nemt at finde en Pecha Kucha-skabelon på nettet.
} 
Et skema skal naturligvis tilpasses det enkelte fag og fagområde og kan udbygges og nuanceres meget mere end vist ovenfor. Men gennem de elementer, der sættes ind, kommunikeres en ramme og en forventning til indhold, som fjerner en del af frustrationen over at skulle finde en god form og et godt indhold.

Når formålet med at anvende studenteroplæg er klart, og formen er tydelig, er forberedelsen længe før oplægget gjort. Herfra foregår arbejdet med studenteroplæg i selve undervisningslokalet.

\section{Lige før oplægget}

Netop på grund af studenteroplæggets symmetriske karakter - der kommunikeres til medstuderende - er det særligt vigtigt, at underviseren sætter rammen for studenteroplæg i undervisningslokalet. At rammesætning er centralt står at læse allerede hos Carsten Raft i 1945. Det er således ikke en ny indsigt, men ikke desto mindre er det fortsat en overset faktor:

Det er Taleren, der holder Talen - og den maa han selv klare! Men Foreningen eller Arrangørerne har ogsaa et ansvar. Forbereder de Mødet omhyggeligt og godt og indleder Mødets Leder paa den psykologisk rigtige Maade, kan det hjælpe Taleren stærkt; men er der sjusket med Mødets Forberedelse og Start, er det uhyre svært for selv den bedste taler at stride sig op mod de Vanskeligheder som ganske urimeligt og unyttigt er lagt ham i vejen. (Raft, 1945: 16).

Det er således vigtigt, at underviseren legitimerer oplægsholderen, repeterer formålet og rammen og giver ordet videre. Derved låner oplæegsholderen lidt af underviserens troværdighed og starter et bedre sted, end hvis han eller hun selv skal legitimere sin position som oplægsholder. Lader underviseren oplægsholderen selv tage ordet, sætte rammen og forklare lytternes rolle, får oplægsholderen et ansvar for processen, som rettelig tilfalder underviseren. En måde at legitimere en oplægsholder på er at introducere oplægsholder, formål og emne. I akademiske sammenhænge opleves det ofte, at der læses højt af vedkommendes meritter, og det er selvfølgelig sjældent muligt om studerende. Men indled med: den studerendes navn, studieretning (med mindre alle har samme studieretning), emne for oplægget og den rolle, lytterne har under oplægget. Små kommentarer som "jeg ser meget frem til at diskutere denne tekst med jer" eller "dagens emne er centralt for faget fordi ..." er ligeledes med til at sætte oplægsholderen og emnet ind i en ramme, hvor det er indholdet mere end personen, der er det interessante.

En del studerende bliver nervøse, når de skal holde oplæg. Selvom det fra et underviserperspektiv kan forekomme underligt, når det bare er deres medstuderende, der lytter, er det netop vigtigt at være opmærksom på troværdighed. Etos eller troværdighed hos taleren er en vigtig parameter for, om et oplæg lykkes. Initialetos, eller den troværdighed, som oplægsholderen har hos sine lyttere indledningsvist, påvirkes markant af lytternes repræsentation af oplægsholderen (McCroskey, 2001:87). Det er således ikke nok, at det, man siger, er rigtigt. Lytterne skal også tillægge oplægsholderen en troværdighed. I en symmetrisk situation, hvor oplægsholderen er under uddannelse, er initialetos notorisk lavt. Det kan underviseren mindske ved at sætte scenen for oplægsholderen og derved at udvise tiltro til den studerendes evner. Samtidig skal underviseren naturligvis være opmærksom på, at selvom det ikke er en bedømmelsessituation, så er der elementer af noget asymmetrisk, fordi underviseren skal eksaminere på et tidspunkt og i øvrigt er bedre inde i emnet end oplægsholderen.

Nervøsitet viser sig på mange måder. Enten som rysten på hænderne, røde pletter på halsen, udsving på stemmen, flakkende blik eller hektisk bevægelse. Det er meget naturligt og er et udslag af, at oplægsholderen er fysisk opmærksom på, at der skal præsteres. Lidt adrenalin er udmærket, men for meget kan naturligvis være forstyrrende. Me- 
gen nervøsitet kan overkommes i løbet af de første to minutter af oplægget. Så hvis en studerende på forhånd giver udtryk for nervøsitet, er det en fordel at indstudere de første minutter af oplægget ret nøje, for når de går godt, slapper kroppen mere af. Ligeledes er det indsatsen værd at lave en sikker afslutning. Det er med til at holde den etos, der er opbygget gennem oplægget. Hvis oplægget ender sikkert og troværdigt, er det både med til at styrke etos og med til at give oplevelsen af, at oplægget gik godt.

Gode indledninger består af:

- Relevansen for lytterne - en case, et eksempel eller konkrete anvendelsesmuligheder.

- Budskabet eller essensen af det, der kommer - det giver lytterne et pejlemærke at lytte med og viser en vinkel på det, der skal gennemgås.

- Et overblik over oplæggets elementer.

Ligeledes har gode afslutninger nogle karakteristika:

- Vend tilbage til indledningens case, eksempel eller anvendelsesmuligheder.

- Opsummer det mest centrale.

- Vis tydeligt med tale og kropssprog, at oplægget er slut. Fx "Det var, hvad jeg havde valgt at tage med i mit oplæg" eller "Tak fordi i lyttede, nu ser jeg frem til at diskutere det med jer" eller simpelthen "Tak for jeres opmærksomhed".

Hvis oplægget afsluttes tydeligt, er lytterne trygge. En oplægsholder, der afslutter med "Det var det, nu har jeg ikke mere" eller "Nå! Det var sidste slide ...", mister troværdighed.

En ting er naturligvis oplægsholderens etos og velbefindende. En anden ting er lytternes. Også lytterne har ekstra behov for faste rammer i en symmetrisk kommunikationssituation. Så hvis der skal gives feedback, eller lytterne skal have et særligt fokus undervejs i oplægget, er det vigtigt at få det på plads i god tid, før oplægget påbegyndes. I en symmetrisk kommunikationssituation er det en fordel at trække relationen mellem de studerende ud af det rent sociale rum. Derfor er det ofte en fordel at give tilhørerne en funktion også. Det kan være et fokusområde til feedback eller at være i stand til at stille tre spørgsmål til oplægsholderen bagefter. Dette behandles nærmere nedenfor i afsnittet "Efter oplægget".

Nu er scenen overgivet til oplægsholderen, og tilhørerne kender deres funktion. Det er tid til selve oplægget.

\section{Under oplægget}

Mennesker (og andre primater) spejler hinanden (Ferrari, Gallese, Rizzolatti \& Fogassi, 2003; Hickok, 2014). Det er fundamentalt for vores måde at kommunikere på, at vi afkoder hinandens intentioner og sindstilstande ved at se, høre og mærke (og til dels også lugte) hinanden. ${ }^{3}$ Det er relevant for studenteroplæg, fordi denne forståelse af hinanden påvirker kommunikationen.

Tilhørerne og underviseren kan på ganske kort tid ødelægge et ellers udmærket tilrette-

\footnotetext{
${ }^{3}$ Teorien om spejIneuroner har lidt en omtumlet tilværelse. Hickok betegner den som en teori, der har fået en tilværelse uden for laboratoriet, som der ikke er forskningsmæssig evidens for. Den grundlæggende teori var, at nogle af de neuroner. der er aktive. når vi selv udfører en handling. også er aktive. når vi ser andre af samme art udføre en handling (Ferrari, Gallese, Rizzolatti, \& Fogassi, 2003). En afledt konklusion af dette blev, at alt fra kommunikation til empati kan tilskrives spejlneuroner. Dette tilbageviser Hickok (2014). Men effekten af, at vi forstår hinanden ved at sanse hinanden, tilbageviser han ikke. Han tilskriver det blot ikke neuroner men derimod det, at hjerne og krop er tæt forbundne, og at vi lærer og forstår ved at imitere hinanden.
} 
lagt studenteroplæg ved at fremstå ligeglade, skeptiske eller engagerede i noget andet og mere spændende. Under oplægget er det således vigtigt, at underviseren er engageret i det, der foregår. Ligeledes har de øvrige studerende en rolle at spille. At gøre dem opmærksomme på dette ansvar - at man populært sagt ikke får bedre oplæg, end man har fortjent som lytter - er et underviseransvar. Om der skal opstilles regler for brug af IT under studenteroplæg, om bordene skal flyttes eller, hvordan det håndteres, er en smagssag. Men det er vigtigt at være opmærksom på, at markører som øjenkontakt, små nik og en venlig attitude er en væsentlig hjælp for oplægsholderen. For at illustrere dette kan følgende lille øvelse gennemføres:

- Bed de studerende fortælle sidemanden om et eller andet dagligdags ( $f x$ hvad de har lavet i morges eller, hvad de synes, var det mest interessante i dagens tekst).

- I plenum: lad dem redegøre for hvordan den lyttende part agerede.

- Bed dem nu gentage øvelsen, men hvor den, der lytter, gør det modsatte af, hvad en lytter normalt vil gøre

- I plenum: lad dem redegøre for hvordan det oplevedes både for taler og lytter.

Resultatet af øvelsen er typisk, at det er svært at holde tråden, når man modspejles. Det er svært at huske, fokusere og færdiggøre sætninger for taleren. For lytteren kan det ligeledes være grænseoverskridende at være "uhøflig". Lad de studerende overføre den gode lyttepraksis til situationer, hvor de hører oplæg fra hinanden, og undgå den modspejlende attitude.

Ved at have fokus på at trække oplægget ud af den sociale relation mellem studerende og ved at have fokus på troværdighed i en symmetrisk kommunikationssituation, hjælpes den studerende godt på vej til at få en positiv oplevelse med at holde oplæg. Når oplægget er slut, er det vigtigt ikke at lade det stå for sig selv men at give feedback eller lægge op til diskussion.

\section{Efter oplægget}

Når oplægget er afsluttet, er det underviserens rolle at agere moderator. Jo mere de studerende selv arbejder sammen om at højne forståelse og diskutere forskellige positioner desto bedre. Underviserens funktion er at sikre, at samtalen følger reglerne, og at de studerende ikke arbejder videre med en forståelse, der er forkert.

Der kan vælges flere feedback-strategier. Her vil jeg præsentere tre forskellige vel vidende, at det langt fra er en udtømmende liste. Feedback defineres i denne sammenhæng som kommunikationsprocesser, der lader studerende fokusere på præstation og indhold gennem dialog (Liu \& Carless, 2006). De skal ikke vurdere eller bedømme hinanden, men indgå i dialog for at udvikle faglig argumentation og hjælpe hinanden til at styrke forståelse.

I feedbacken er det igen centralt at være opmærksom på den symmetriske relation. Lige som den er grunden til, at studerende hellere vil høre underviseren end en medstuderende holde oplæg, er den også med til at besværliggøre både at give og modtage feedback. Det skal tages med i overvejelserne, når der vælges feedback-metode. Gives ordet helt frit risikerer debatten at flytte sig fra det faglige til det personlige, hvilket ikke er hensigtsmæssigt. De tre metoder, der her skal præsenteres, er: (1) gruppediskussion, (2) udfyldelse af skema og (3) fokuspunkter.

Den første metode til feedback er gruppediskussion. Efter oplægget opdeles de studerende i et antal grupper, som hver får et fokusområde. Det kan være spørgsmål stillet af den studerende, der holdt oplægget, eller af underviseren. Efter at have diskuteret i den afsatte tid samles der op i plenum. Fordelen ved denne form er, at det er en mindre konfrontatorisk dialog mellem den, der holdt oplægget, og resten af gruppen. Formen lader 
de studerende diskutere et emne inden for oplæggets rammer og giver dem derfor mulighed for at sætte egne ord på emnet.

Den anden feedbackmetode er at arbejde med et skema. Der er udviklet flere skemaer til feedback, men det er vigtigt at anvende et, der er anvendeligt i den givne faglige kontekst. Skemaet udleveres før oplægget, og efterfølgende kan tilhørerne enten selv eller i mindre grupper udfylde det, hvorefter det gennemgås i plenum. Elementer i et sådant skema kunne være:

- Hvad var påstanden i oplægget?

- Hvordan blev påstanden underbygget?

- Hvilket teoretisk fundament bygger påstanden på?

- Hvilke andre fundamenter kunne have været anvendt?

- Hvilke indvendinger blev fremført mod påstanden?

- Hvilke indvendinger kunne der i øvrigt være?

- Hvilke eksempler blev fremført?

- Hvilke andre eksempler kunne have været anvendt?

Disse spørgsmål har deres fundament i Toulmins argumentationsmodel (Toulmin, 2003). Formålet er både at lade tilhørerne afkode argumenterne i oplægget og at tænke videre selv og anvende $\mathrm{fx}$ anden teori eller andre eksempler. Fordelen ved denne form er, at den både regulerer tilhørerne og den, der holder oplægget, til at holde sig til faglig argumentation og til at være opmærksom på, hvordan forskellige metoder og teorier forholder sig til hinanden.

Den sidste form for feedback er at give grupper af tilhørere forskellige fokuspunkter at lytte med. Det kunne være de samme punkter som i skemaet eller nogle helt andre. Den helt enkle måde at bruge fokuspunkter på er at dele tilhørerne op i et grønt og et rødt hold og lade det grønne hold give feedback på alt det, der fungerer godt, og som er tydeligt i oplægget. Det røde hold skal omvendt fokusere på det, der kunne være mere præcist eller bedre i oplægget. Det er vigtigt at bede de studerende være meget konkrete i deres feedback, så det ikke alene bliver "det var fint nok" eller "det brød jeg mig bare ikke så meget om".

Gennem en eller flere feedbackmetoder øves hele holdets evne til at anvende fagets sprog, og det trænes i at lytte efter argumenter og forskelle i disse.

\section{Studenteroplæg som læringsaktivitet}

Som fremført ovenfor så er en struktureret tilgang til studenteroplæg med til at øge legitimiteten og udkommet af selv samme.

Selvom de studerende måtte have modstand mod at deltage i og holde oplæg for hinanden, er det en god måde at lade studerende arbejde med faget på uden at være under direkte bedømmelse. De elementer, man som underviser skal være opmærksom på, er:

- at legitimere aktiviteten som en del af faget

- $\quad$ at give den studerende, der holder oplæg, den bedste etosplatform

- $\quad$ at hjælpe oplægsholderen ved at være nærværende under oplægget

- at styre feedbacken, så den ikke bliver personlig men faglig.

Overholdes disse simple regler, trænes de studerende i at stå foran hinanden, i at tilrettelægge et oplæg og i at tale fagligt om deres stofområde. Fokus i denne tilgang er på at tale frit og at finde ind til hvordan et stofområde skal forstås og fortolkes. Som nævnt indledningsvist er det altså ikke afgørende, at oplægget er sprogligt perfekt, men at det er indholdsmæssigt interessant, og at de studerende sammen når en dybere forståelse af 
et emne, både som oplægsholdere og tilhørere. Men rammesætningen og ansvaret for et højt fagligt niveau er og bliver underviserens.

Linda Greve er forfatter til bøgerne Den gode præsentation (Samfundslitteratur 2010) samt Forandrende ledelseskommunikation (Samfundslitteratur 2012) sammen med Steen Hildebrandt. Desuden er hun medredaktør på antologien Entreprenørskabsundervisning (Aarhus Universitetsforlag 2011) sammen med Anne Kirketerp Linstad. Linda er en erfaren underviser og oplægsholder på kurser på både bachelor-, kandidat og ph.d.-niveau i præsentationsteknik og undervisningsmetode.

\section{Litteratur}

Bhatti, Y. \& Grøn, C. H. (2014). Det er det, de unge vil have. En analyse af studerendes præferencer i relation til undervisning. Dansk Universitetspæedagogisk Tidsskrift, 9(16), 96-112.

Ferrari, P. F., Gallese, V., Rizzolatti, G. \& Fogassi, L. (2003). Mirror neurons responding to the observation of ingestive and communicative mouth actions in the monkey ventral premotor cortex. European Journal of Neuroscience, 178),1703-1714.

Greve, L. (2011). Den gode præesentation: akademisk mundtlig fremstilling og personlig kommunikation. Frederiksberg: Samfundslitteratur.

Hickok, G. (2014). The Myth of Mirror Neurons: The Real Neuroscience of Communication and Cognition. New York: W. W. Norton \& Company.

Klentzin, J. C., Paladino, E. B., J ohnston, B \& Devine, C (2010). Pecha Kucha: using "lightning talk" in university instruction. Reference Services Review, 38(1), 158167. http://doi.org/10.1108/00907321011020798

Liu, N.-F. \& Carless, D. (2006). Peer feedback: the learning element of peer assessment. Teaching in Higher Education, 11(3), 279-290. http://doi.org/10.1080/13562510600680582

MacAlpine, J. M. K. (1999). I mproving and encouraging peer assessment of student presentations. Assessment \& Evaluation in Higher Education, 24(1), 15-25. http://doi.org/10.1080/0260293990240102

McCroskey, J. C. (2001). An Introduction to Rhetorical Communication. Boston: Allyn and Bacon.

Ong, W. J. (2013). Orality and Literacy: 30th Anniversary Edition. London: Routledge.

Raft, C. (1945). Taler-Teknik - Haandbog for Talere (3. ed.). København: C. A. Reitzels Forlag.

Toulmin, S. E. (2003). The Uses of Argument. Cambridge: Cambridge University Press. 